\title{
顎関節雑音を有する咀嚼系機能障害患者に対するバイト プレーン療法と低出力ダイオードレーザー療法の効果 The Effect of Bite Plane and Diode Laser Treatment in CMD Patients with TMJ Noise
}

小林義带，志頨博，秋山仁志

Yoshinori KOBAYASHI, Hiroshi SHIGA, and Hitoshi AKIYAMA

日本菌科大学歯学部曾科補緅学教室第 1 講座

The Nippon Dental University, School of Dentistry at Tokyo, Departinent of Partial and Complete Denture

\section{1. 緒言}

咀哷系機能障害の主要症状のうち、顎関節雑 音は非観血的潦法では最も残存率が高くい、ま たその発生機序については不明瞭な点を多く残 している。

著者らは、顎関節音の機能的診断法の確立を 目的として、マイクロフォンで記録した開開口 運動時の顎関節音を周波数分析によって、音の 性状を定量的に評価するシステムを開発し、分 析を進めている。すでに、顎関節音の検索に際 しては、波形分析よりも周波数分析の方が有効

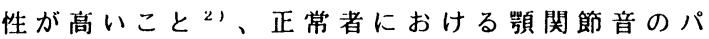
ワースペクトルは、周波数帯域がほほ $100 \mathrm{~Hz}$. 以 下に限定される同一パターンを呈すること ${ }^{31} 、$ 咀缶系機能障害患者における顎関節音のパワ一 スペクトルは、100 Hz以上にも周波数成分の強 調がみられ、正常者のそれとは明らかに異なる パターンを示すこと`1、顎関節音の絮積 $80 \%$ 周 波数值は、顎関節音の定量的評価の有効な指標 になることらを報告してきた。

今回は、顎関節雑音を有する咀啲系機能障害 㭧者に対するレーザー撩法の効果を客観的に詊 価する目的で、保存撩法で改善が認められなか った患者に低出力ダイオードレーザーを 1 日お きに 5 四、さらに 2 週間おきに 2 㝳然射し、然

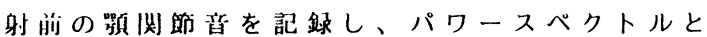
糸秒 $80 \%$ 周波数做を分析した。また、バイトブ レーン療法後（レーザー照射開始前）と開始 7 週間後における咀嚼運動を記録し、咀嚼運動の 安定性についても分析した。

\section{2 . 研究方法}

\section{1 被娩者と治療経過}

被験者は、44瓷の女性で、右側頚部・肩部・ 手腕部の疼痛と開口時の右侧顎関節 を主訴として来院した。心理テスト、血液一般。 血清学的㮩查、また全身既往、家族歴に特記す ベき主事項は認められなかった。Michigan型バ イトブレーンを装着し、約 40 週間にわたり、 3 週間隔で調整を継続したところ、右側頸部・有 部・手腕部の疼痛は消退したが、装着 8 週間後 に軽減した右側顎関節部のclickingは以後何ら 変化しなかった。そこで、右側顎関節部への低 出力ダイオードレーザー療法を試みた。レーザ 一撩法は、東京医研社製の低出力タイオードレ ーザーTE830-100(GaA1As半導体レーザー、波長: $830 \mathrm{~nm}$ 、光出力: $25 \mathrm{~mW} 、 50 \mathrm{~mW} 、 75 \mathrm{~mW} 、 100 \mathrm{~mW}$ の 4 段階出力、出力モード：連続出力）を用い、前 述のように 1 日おきに 5 回、さらに 2 週間おき に2回照射した。

\section{2 記録方法と装置}

被娩者は、頭部を固定せずにフランクフルト 平面が水平となるようにリラックスさせた状態 で、蒾科用治掎子に坐らせた。

\section{2 .1 咀噭连動の記録}

嵖啲迷動は、Myotronics 社製Mandibular Kinesiograph K-5型を用いて、主明啝侧でガム 咀㬐を行わせた時の30ストロークにおける切歯 点の運動をTEAC社製データレコーダー (XR-50) に記録した。 


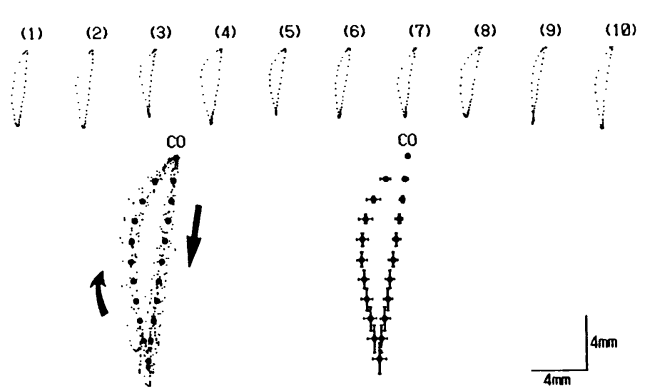

図1．本研究の柋識法により自動的に分割された咀哷 ストロークおよび平均経路、標準偏差

表1 . 開口時側方成分、閉口時側方成分、垂直成分

\begin{tabular}{rrrrrrrr}
\hline \multicolumn{7}{c}{ Average Path (Mean \& SD) } \\
\hline \multicolumn{7}{c}{ Lot.(openIng) } \\
Mean & SD & \multicolumn{2}{c}{ Lot.(clos Mng) } & \multicolumn{2}{c}{$\begin{array}{c}\text { Vertlcal } \\
\text { Mean }\end{array}$} & SD \\
\hline level 0 & 0.00 & 0.03 & 0.00 & 0.03 & 0.00 & 0.04 \\
1 & -0.06 & 0.16 & 1.69 & 0.22 & 1.71 & 0.20 \\
2 & 0.08 & 0.20 & 2.64 & 0.27 & 3.12 & 0.27 \\
3 & 0.26 & 0.23 & 3.16 & 0.36 & 4.52 & 0.36 \\
4 & 0.43 & 0.31 & 3.35 & 0.41 & 5.93 & 0.46 \\
5 & 0.64 & 0.39 & 3.32 & 0.49 & 7.33 & 0.56 \\
6 & 0.83 & 0.46 & 3.15 & 0.54 & 8.74 & 0.66 \\
7 & 1.05 & 0.47 & 2.88 & 0.56 & 10.14 & 0.76 \\
8 & 1.24 & 0.46 & 2.62 & 0.61 & 11.55 & 0.86 \\
9 & 1.42 & 0.53 & 2.33 & 0.64 & 12.96 & 0.97 \\
10 & 1.88 & 0.68 & 1.88 & 0.68 & 14.36 & 1.07 \\
\hline
\end{tabular}

表2 . 開口相時間、閉口相時間、咬合相時間、cycle time

\begin{tabular}{rrcccc}
\hline & & Opening & Closing & Occluding & Cycle time \\
\hline 1 & $:$ & 0.21 & 0.17 & 0.20 & 0.58 \\
2 & $:$ & 0.24 & 0.15 & 0.19 & 0.58 \\
3 & $:$ & 0.21 & 0.18 & 0.19 & 0.58 \\
4 & $:$ & 0.22 & 0.17 & 0.19 & 0.58 \\
5 & $:$ & 0.22 & 0.14 & 0.20 & 0.56 \\
6 & $:$ & 0.26 & 0.13 & 0.19 & 0.58 \\
7 & $:$ & 0.21 & 0.17 & 0.19 & 0.57 \\
8 & $:$ & 0.21 & 0.17 & 0.19 & 0.57 \\
9 & $:$ & 0.20 & 0.15 & 0.21 & 0.56 \\
10 & $:$ & 0.19 & 0.17 & 0.19 & 0.55 \\
\hline Mean : & 0.217 & 0.160 & 0.194 & 0.571 \\
SD : & 0.020 & 0.016 & 0.007 & 0.011 \\
\hline
\end{tabular}

\section{2 .2 顎関節音の記 録}

顎関節音は、測定部位（皮成上の外眼触耳 珠の上下的中点とを結ぶ線上の耳珠後縁より 13 $\mathrm{m} m$ の点を平均的顆頭点とし、その点より前下方 約 $20 \mathrm{~mm}$ の点）にリオン社製コンタクトマイク (SH01-S03)を両面接着テーブで固定後、被娩者 に開閉口運動をさせ、顎関節音を採取後、マイ クロサイエンス社製 A/D コンバーター (DAS1898XPC) によりアナログ信号を Sample数 8000 、

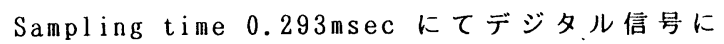
変換し、さらにデジタル波形をグラフィクディ スプレトで確認後、ディスク(PC9801-VM21) に記録した。

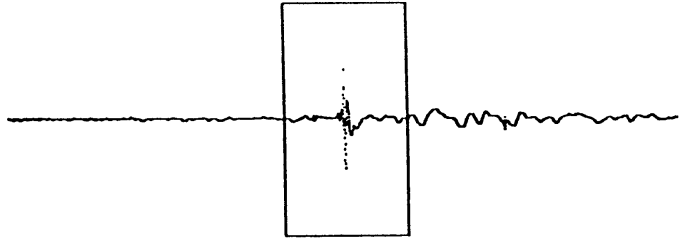

困2．周波数分析を行なう範囲指定
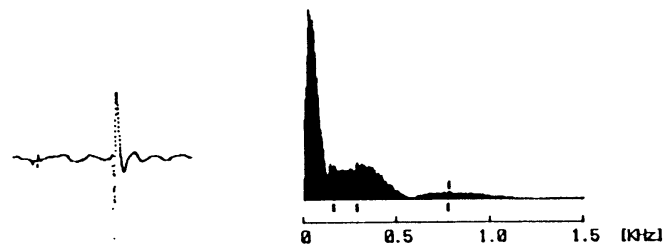

図3。範围指定により求められた顎関節音の 原波形とパワースペクトル

\section{3 分析方法}

\section{3 .1 咀謝運動の分析}

咀嚼運動の分析は、データレコーダーからの 再生記録をA/D コンバーターによりアナログ信 号をSample数 3000 、Sampling time $10 \mathrm{mseck}$ デジタル信号に変換後、教室で開発した咀㗖運 動自動分析システム ${ }^{6}$ を用いて主咀哷側咀嚼時 の咀嚼ストロークを各ストロークに们解し、咀 喟開始後第5 ストロークからの10ストロークに おける運動経路と運動リズムの安定性について、 初診時、バイトブレーン療法後、レーザー療法 後 7 週間との間でそれぞれ比較した。運動経路 については、各ストロークの咬合接触位を基準 として、各ストロークにおける咀㗭パターンを 上下的に10分割して坐標值を求め、この座標值 から半均経路および左右、上下方向の槽準偏差 を算出（表 1 、図1）後、開口時僛方成分、閉 口時側方成分、釷淔成分の各標华偏差を開口量 で徐算する指標（以下 SD/OD と略す）を算出し、 運動経路の安定性を表わす指標にした。

運動リズムについては、各ストロークにお ける開口相時間、閉口相時間、咬合相時間、 cycle timeを算出後、10ストロークの平均時間 と標準偏差を算出し（表2）、各時間の変動係 数を運動リズムの安定性を表わす指標にした。

\section{3 .2 䫑関節音の分析}

頻関節音の分析は、まずディスクに保存した 㴿関節音のデータをグラフィックディスブレイ に再生後、マウスを用いて周波数分析を行う範 


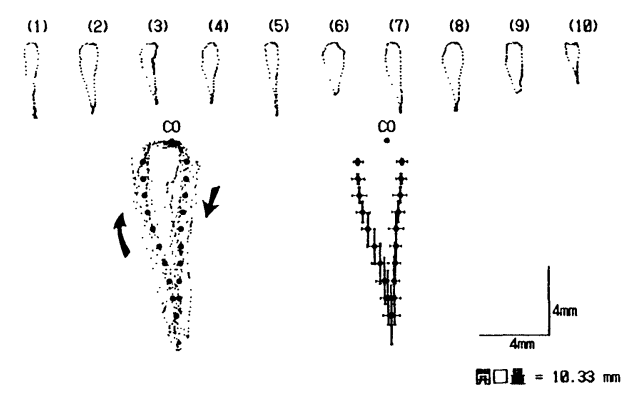

図4．初診時における咀啋開始後第 5〜14ストロークと その平均経路ならびに標準偏差（前頭面）

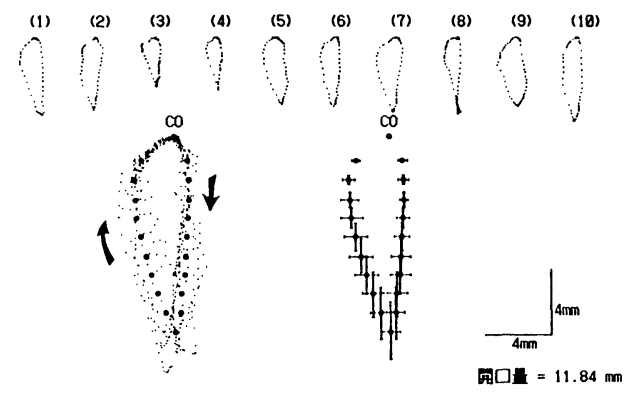

図6 . バイトプレーン療法後における咀哷開始後第 5〜14 ストロークとその平均経路ならびに標準偏差

（前頭面）

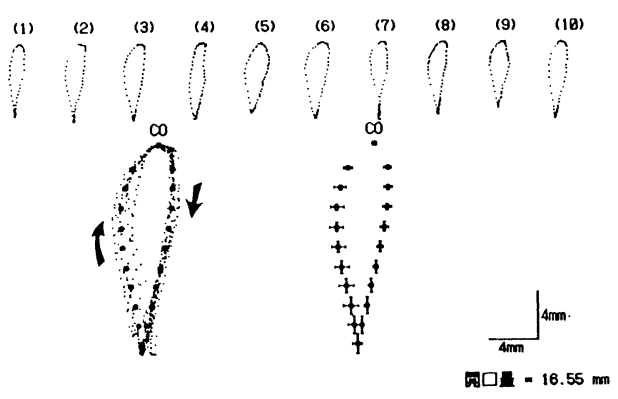

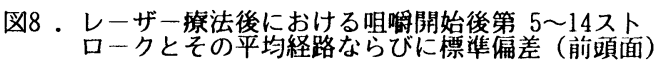

囲を指定する（図2）。次いで、範囲指定によ り得られたデータに対して 7 点平滑化によりス ムージング後、F F. T 処理したものを信号 A、 被娩者が安静時にあると思われる範囲内のデー タに対して 7 点平滑化によりスムージング後、 F F T 処理したものを信号 Bとし、信号 A から 信号 $\mathrm{B}$ を減算したものをその餙囲の求めるパワ ースペクトルとし（図３）、さらにそのパワー スペクトルから累積 $80 \%$ 周波数值とを算出し、 初診時、レーザー治療開始前、開始 2 日後、 4 日後、 6 日後、 8 日後、 3 週間後、 5 週間後、 7 週間後の経過を観察した。

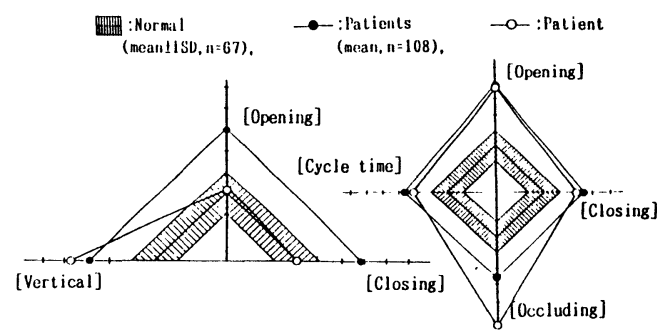

経路の安定性林ムの安定性

困5．初診時における運動経路とリズムの安定性

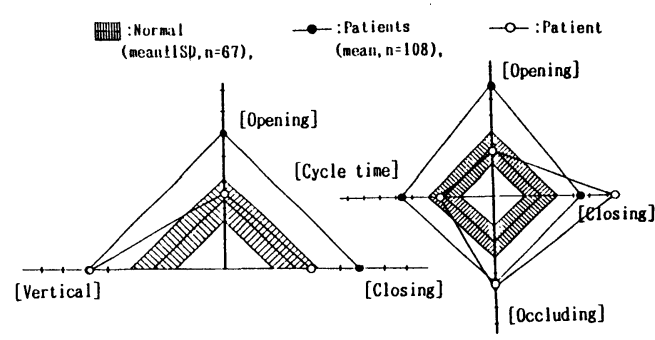

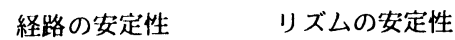

困7．バイトプレ一ン療法後における運動経路と

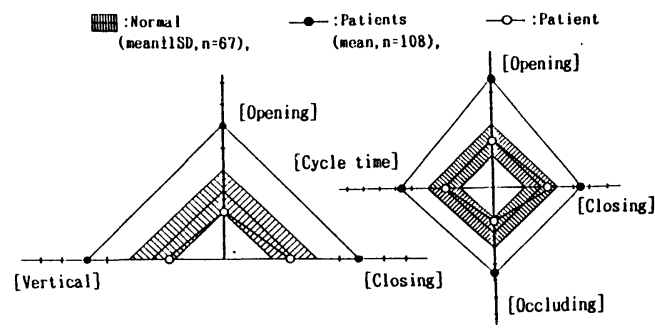

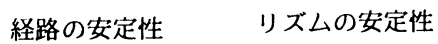

困9．レーザー撩法後における運動経路とリズム

3. 結果および考察

\section{1 咀嘾運動について}

3.1 .1 初診時の咀唃運動

運動経路は、咬合位付近の咀㛵幅が大きく、 開口するにしたがって咀唧幅が著明に娍少する 特異的パターンを呈していた。また、開口時に 運動の停止あるいは運動の制止が推察されるパ ターンが認められ、さらに右咀嗘側にもかかわ らず左側へ開口し、開口から閉ロへの変極点も 左側に位置しでいた（図4）。

運動経路の安定性は、垂直成分のSD/OD が正 
常飭四外にあり不安定だったが、開口時側方成 分と閉口時側方成分の両SD/OD が正常範盲内に あり安定していた。一方、運動リズムの安定性 は、開口相時間、閉口相時間、咬合相時間、 cycle t i m e の各変動係数がいずれも正常餙粗 外にあり、極めて不安定だった（図 5 ）。

したがって、初診時の勗哷運動は、患者が独 自のパターン形成を行うことによって䢖動経路 を安定することができたが、その経路が恭常な 特異的パターンであるために運動リズムが揁な われ、不安定になったものと考えられる。

\section{1 .2 バイトブレーン療法後の咀踊遇動}

運動経路は、初診時とは明らかに珙なり、非 作業側へ開口後、作業側へ向かい、その後中心 咬合位へconvexを呈して戻るパターンを呈して いた。また、左側への偏位や運動の停止あるい は運動の制止などが著明に減少した（図6）。

運動経路の安定性は、初診時と同様に垂㨁成 分のSD/OD が正常範囲外にあり不安定だったが、 開口時側方成分と閉口時侧方成分の両SD/OD が 正常範囲内にあり安定していた。一方、運動リ ズムの安定性は、閉口相時間、咬合相時間の両 変動係数が正常範囲外にあり、不安定だったが、 開口相時間、cycle timeの両变動係数が正常範 曲内に回復し、初診時よりも安定していた（図 7 )。

バイトブレーン療法後の咀哷運動は、経路の パターン形成が改善され、正常者に近似するパ ターンに変化してきたために初診時よりもスム 一ズになり、リズムが回復してきたものと思わ れる。

\section{1 .3 レーザー療法 7 週間後の咀䙳運動}

運動経路は、バイトブレーン療法後よりもさ らに安定し、各ストロークともにほほ同じ経路 をとった（図8）。

運動リズムの安定性は、各指標がいずれも正 常範囲内に回復し、極めて安定していた(図9)。 レーサー療法後の咀㧹運動は、さらに経路の パターン形成が改善され、正常者のパターンに 変化したためにバイトブレーン撩法後よりもさ らにスムーズになり、経路、リズムともに正常 範囲に回復したものと思われる。

\section{2 䫑関節音について}

\section{2 .1 䫑関節音の原波形}

顎関節音の原波形は、初診時、バイトブレー ン療法後（レーザー撩法開始前）、レーザー撩 法開始 2 日後、 4 日後、 6 日後、 8 日後では短 周期の複数の振動波形を示し、各波形間に相違 が認められなかった。 3 週間後、 5 週間後では 短周期の振動波形の減少が誌められ、7週閉後 では短周期の振動波形が消失し（図10）、正常 者の原波形に近似した。

\section{2 .2 パワースペクトルのパターン}

パワースペクトルのパターンは、初診時、バ イトブレーン撩法後、レーザー撩法開始 2 日後、 4 日後、 6 日後、 8 日後、 3 週間後では、 100 $\mathrm{Hz}$ 以上の周波数带域でも周波数成分の強調がみ られ、100 HzW下成分が多く、100 Hz以上の 成分が周波数值の增加にともない徐々に減少す る同一パターンを呈した。しかしながら、治撩 経過とともに $100 \mathrm{~Hz}$ 以上の周波数成分が減少し、 5 週間後ではそれがほとんど消失し、7週間後 では正常者と同様に $100 \mathrm{~Hz}$ 以下に限局するパタ ーンを示した（図11）。

$100 \mathrm{~Hz}$ 以上の周波数成分は初診時に対して治 療経過とともに減少し、顎関節音のパワースペ クトルのパターンに低域シフトが認められたが、 これは顎関節雑音が残存しているものの、音の 性状がレーザー撩法により変化したことを示す ものと考えられる。そこで、この顎関節音の性 状の変化を累䅡 $80 \%$ 周波数值を用いて定量的に 観察してみた。

\section{2 .3 累積 $80 \%$ 周波数值}

初診時、バイトブレーン療法後、レーザ一療 法開始 2 日後、 4 日後、 6 日後、 8 日後、 3 週 間後、 5 週間後、 7 週間後における顎関節音の パワースペクトルから算出した嗉䅡 $80 \%$ 周波数 值は、治撩の経過とともに徐々に小さくなり、 7 週間後に正常範囲内に回復した（図12）。こ のことは、治撩経過における顎関節音の性状の 変化が累積 $80 \%$ 周波数值を用いて観祭すること により、より明確になったことを示しており、 累積 $80 \%$ 周波数值が顎関節音の診断の定量的評 価のみならず、治㟫経逈の判定にとつても有効 な指標になる可能性を示唆するものと考えられ る。

以上のことから、低出力ダイオードレーザー が、保存可逆的療法で顎関節雑音に著効が認め られなかった顎関節症患者に対して有効な治療 
[ First examination ]

[ After 8 days]

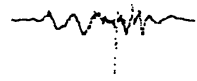

[ Before ]

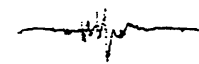

[ After 2 days ]

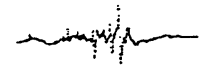

[ After 5 weeks]

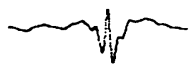

[ After 7 weeks ]

[ After 4 days]
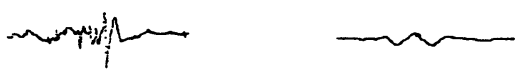

\section{[ After 6 days ]}<smiles>CCCC(C)CCC</smiles>
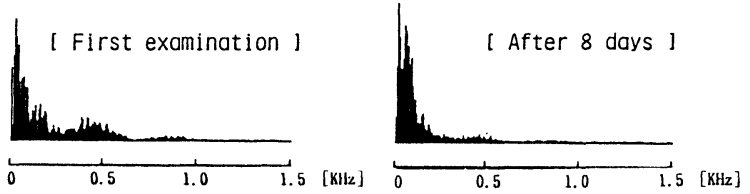

[ After 3 weeks ]
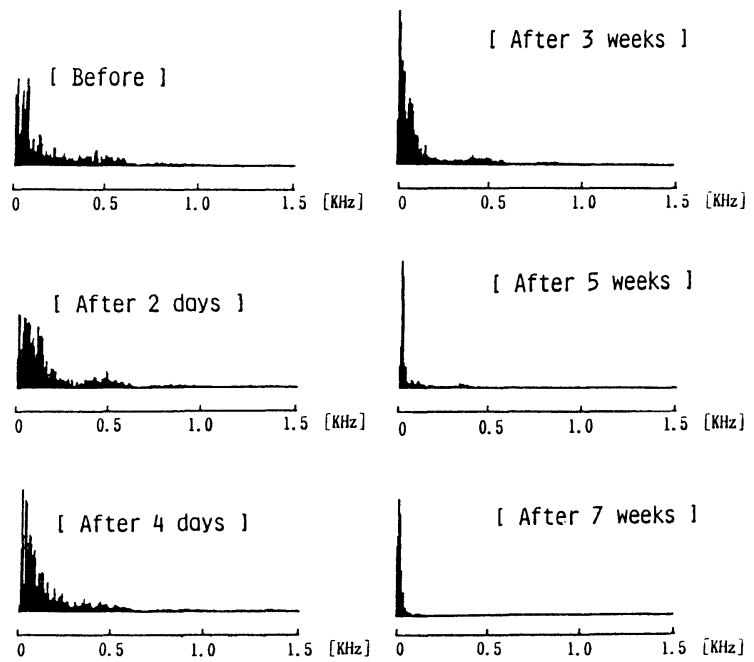

図10、顎関節音の原波形

法の1つになる可能性が示唆された。

\section{4. 結 論}

\section{1 咀程運動}

\section{1 .1 初診時の咀嚼運動}

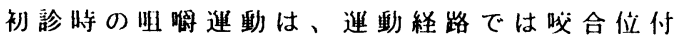
近の咀㗖幅が大きく、開口するにしたがって咀 嘶幅が著明に減少する特翼的パターンを呈して いた。また、運動経路の安定性では比較的安定 していたが、運動リズムの安定性では各指標值 がいずれも正常範囲外にあり、極めて不安定だ った。

4.1 .2 バイトブレーン療法後の咀㧹運動

バイトブレーン療法後の咀啲運動は、運動経 路では初診時とは明らかに異なり、非作業側へ 開口後、作業侧へ向かい、その後中心咬合位へ

図11、顎関節音のパワースペクトル
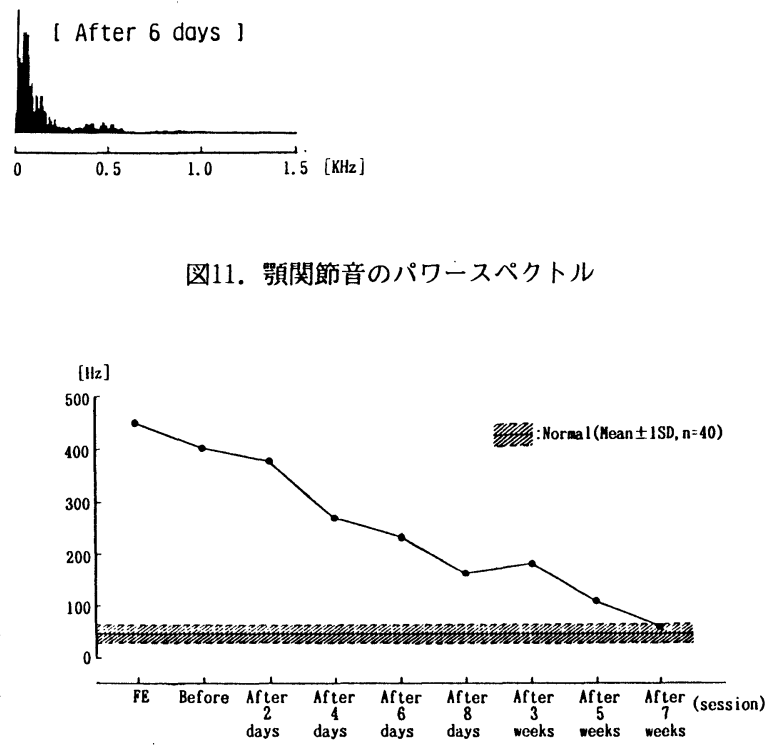

図12. 顎関節音の累積 $80 \%$ 周波数值

convexを呈して戻るパターンを呈した。また、 運動経路の安定性では初診時と同様だったが、 運動リズムの安定性では閉口相時間、咬合相時 間の両变動係数が正常範用外にあり、不安定で あったものの、開口相時間、cycle timeの屾変 
動係数が正常範囲内に回復し、初診時よりも安 定した。

\section{1 .3 レーサー療法 7 週間後の咀㬭遇動}

レーサー療法 7 週間後の咀㗖運動は、運動経 路ではバイトブレーン療法後よりもさらに安定 し、各ストロークともにほほ同じ経路をとった。 また、運動経路と運動リズムの安定性では各指 標がいずれも正常範囲内に回復し、極めて安定 した。

\section{2 影関節 音}

\section{2 .1 䫑関節音の原波形}

顎関節音の原波形は、初診時、バイトブレ一 ン療法後（レーザー療法開始前）、レーザー療 法開始 2 日後、 4 日後、 6 日後、 8 日後では短 周期の複数の振動波形を示し、各波形間に相違 が認められなかった。 3 週間後、 5 週間後では 短周期の振動波形の減少が認められ、7週間後 では短周期の振動波形が消失し、正常者の原波 形に近似した。

4.2 .2 パワースペクトルのパターン

パワースペクトルのパターンは、初診時、バ イトブレーン療法後、レーザー療法開始 2 日後、 4 日後、 6 日後、 8 日後、 3 週間後では、 100 $\mathrm{Hz}$ 以上の周波数帯域でも周波数成分の強調がみ られたが、治療経過とともに $100 \mathrm{~Hz}$ 以上の周波 数成分が減少し、5週間後ではほとんど消失し、 7 週間後では正常者と同様に $100 \mathrm{~Hz}$ 以下に限局 するパターンを示した。

\section{2 .3 累栍 $80 \%$ 周波数值}

初診時、バイトブレーン療法後、レーザー療 法開始 2 日後、 4 日後、 6 日後、 8 日後、 3 週 間後、 5 週間後、 7 週間後における影関節音の パワースペクトルから算出した累積 $80 \%$ 周波数 值は、治療の経過とともに徐々に小さくなり、 7 週間後に正常範囲に回復した。以上のことか ら、低出力ダイオードレーザーが、保存可逆的 撩法で顎関節雑音に著効が諗められなかった顎 荓䬣证急者に刘して有效な治撜法の1つになる 可能性が示唆された。

\section{5 . 文献}

1)佐藤哲郎，小林義典：咀㧹系機能障害に対 するMichigan型全曾列接触型bite planeの応用
方法に関する臨朱的研究，匊学，75:818-864, 1987.

2)秋山仁志，志賀博，作藤哲郎，小林義典： 顎関節音に関する踄床的研究，第 1 報分析方法 について, 米学, 76:218-219, 1988 .

3 ) 秋山仁志，志貿博，石原裕之，小林義典： 顎関節音に関する䠛床的研究，第 3 報正常者に おける顎関節音のパワースペクトル分析につい て, 雬学, 76:851-852, 1988.

4 ) 秋山仁志，志賀博，小林義典：顎関節音に 関する臨休的研究，第 4 報正常者と咀㗖系機能 障害患者のパワースペクトル分析による比較， 第 1 回日本顎関節学会総会講演抄録集，63頁， 1988.

5 ) 志賀博，芳賀景呞，秋山仁志，小林義典： 顎関節音に関する臨床的研究，第 7 報周波数分 析による䫟関節音の定量的評価法, 下䫟運動㙨 能と E M G 諞文集，第 7 輯，125-130 頁，顎口 腔機能研究会, 長崎, 1988 .

6 ) 志貿博，林清平，浜中秀由音，小林義典： 下頢運動記録装㯰とパーソナル・コンピュータ 一により構成した下顎運動自動分析システム, 下額運動機能と E M G 論文集，第 5 輯，175180 頁, 顎口腔機能研究会, 新潟, 1987. 